\title{
ELECTROCHROMISM AND ELECTROCHROMIC WINDOWS
}

\author{
G. CAMPET, J. PORTIER, S.J. WEN \\ Laboratoire de Chimie du Solide du CNRS, 351, Cours de la Libération. 33405 Talence Cédex \\ (France) \\ B. MOREL, M. BOURREL, J.M. CHABAGNO \\ Groupe de Recherches de Lacq du Groupe Elf. Aquitaine, B.P. 34. 64170. Artix (France) \\ (Received July 29, 1991; in final form August 22, 1991)
}

The properties of electrochromic thin film materials, i.e., those that can be reversibly colored by the passage of charge, are described. The application of some of these thin film compounds for the development of electrochromic windows is discussed.

\section{INTRODUCTION}

Electrochromism is the phenomenon related to changes in color induced in related thin film materials by a reversible electrochemical process. More precisely, electrochromism can be defined as a persistent but reversible optical change produced electrochemically in selected thin film compounds, designated as electrochromic materials $(\mathrm{ECM})^{1}$.

The focus of this report will be on the performances of a new ion-insertion ECM and of electrochromic windows (i.e., "smart windows" for the control of light transmission in windows) based on such a ECM.

\section{ION-INSERTION ELECTROCHROMIC MATERIALS, ECM}

These include organic (e.g., diphtaloajanine, tetrathiafulvalene) as well as inorganic compounds. They are characterized by a process that implies the reversible insertion of ions in their lattice.

To ensure electroneutrality, the insertion (desinsertion) of one cation must be accompanied by the injection (departure) of one electron (1):

$$
\mathrm{ECM}+\mathrm{xM}^{+}+\mathrm{xe}^{-} \Leftrightarrow \Rightarrow \mathrm{M}_{\mathrm{x}} \mathrm{ECM}
$$

The following ECM have received by far the most attention ${ }^{2-7}: \mathrm{WO}_{3}$ (colorlessblue), $\mathrm{MoO}_{3}$ (colorless-blue), $\mathrm{V}_{2} \mathrm{O}_{5}$ (pale yellow-blue), $\mathrm{TiO}_{2}$ (colorless-blue), $\mathrm{IrO}_{\mathrm{x}} \mathrm{H}_{\mathrm{x}}$ (black-colorless), $\mathrm{NiO}_{\mathrm{x}} \mathrm{H}_{\mathrm{x}}$ (brown-colorless). 
These inorganic compounds can be divided into two classes:

a/ The oxides with "cathodic coloration" $\mathrm{WO}_{3}, \mathrm{MoO}_{3}, \mathrm{~V}_{2} \mathrm{O}_{5}, \mathrm{TiO}_{2}$. The mechanism of coloration of these film is the double injection of electrons and small chargecompensation cations at opposite interfaces:

$$
\begin{aligned}
& \mathrm{AO}_{\mathrm{n}}+\mathrm{xM}^{+}+\mathrm{xe}^{-} \Leftrightarrow \Rightarrow \begin{array}{l}
\mathrm{M}_{\mathrm{x}} \mathrm{AO}_{\mathrm{n}} \\
\text { colored } \\
\text { colorless } \\
\text { or pale yellow }
\end{array}
\end{aligned}
$$

Thus, the reaction is the reversible electrochemical formation of the corresponding transition metal bronze; $\mathrm{M}$ can be $\mathrm{H}^{+}, \mathrm{Li}^{+}, \mathrm{Na}^{+}$or $\mathrm{Ag}^{+}{ }^{2-4}$.

b/ The oxides with "anodic coloration"- $-\mathrm{IrO}_{x} \mathrm{H}_{y}, \mathrm{NiO}_{x} \mathrm{H}_{y}$, for which reversible charge insertion processes have been mainly observed in aqueous electrolytes ${ }^{5-7}$.

The electrochemical reaction process for iridium-oxide based films is still a matter of some controversy ${ }^{5}$. Indeed, two opposing mechanisms have been put forward. One is that in coloration, charge compensation occurs by proton extraction [e.g. (3)], whereas the second model is that coloration occurs by hydroxyl ion insertion [e.g. (4)]:

$$
\mathrm{Ir}_{2} \mathrm{O}_{3-\mathrm{x}}(\mathrm{OH})_{2 \mathrm{x}} \longleftrightarrow \mathrm{Ir}_{2} \mathrm{O}_{4}(\mathrm{x}-1) \mathrm{H}_{2} \mathrm{O}+2 \mathrm{H}^{+}+2 \mathrm{e}^{-}
$$

or

$$
\begin{aligned}
\begin{array}{l}
\mathrm{Ir}_{2} \mathrm{O}_{3-\mathrm{x}}(\mathrm{OH})_{2 \mathrm{x}}+2 \mathrm{OH}^{-} \longleftrightarrow \\
\text { clear }\left(\mathrm{Ir}^{3+}\right)
\end{array} & \mathrm{Ir}_{2} \mathrm{O}_{4}(\mathrm{x}+1) \mathrm{H}_{2} \mathrm{O}+2 \mathrm{e}^{-} \\
& \text {black }\left(\mathrm{Ir}^{4+}\right)
\end{aligned}
$$

Iridium oxyhydroxide films can be obtained by anodic growth or by sputtering on ITO coated glass support ${ }^{1}$. It has been established that properly deposited iridium oxide films may assume electrochromic response times of the order of $200 \mathrm{~ms}$. Such a fast response, however, is in part counterbalanced by the relatively poor color contrast (transparent to grey) and by the high cost of the material ${ }^{1}$.

In the case of nickel oxyhydroxide films the anodic color change is more pronounced as it varies from colorless to dark brown $n^{6-7}$. However, as with iridium oxyhydroxide films, the (de)coloration mechanisms for nickel oxyhydroxide are not totally clarified. Generally, the reaction:

$$
\begin{array}{ll}
\mathrm{Ni}(\mathrm{OH})_{2} \longleftrightarrow & \mathrm{NiOOH}+\mathrm{H}^{+}+\mathrm{e}^{-} \\
\text {clear }\left(\mathrm{Ni}^{\mathrm{II}}\right) & \text { brown }\left(\mathrm{Ni}^{\mathrm{III}}\right)
\end{array}
$$

is assumed ${ }^{6}$. However the following scheme is also reported ${ }^{1}$ :

$$
\underset{\text { clear }}{\mathrm{Ni}(\mathrm{OH})_{2}}+\mathrm{OH}^{-} \longleftrightarrow \underset{\text { brown }}{\mathrm{NiOOH}}+\mathrm{H}_{2} \mathrm{O}+\mathrm{e}^{-}
$$


Finally, Hugot-le Goff et al. recently showed that in porous films the electrochromic effect would result from the reaction ${ }^{7}$ :

$$
\mathrm{NiO}+\mathrm{OH}^{-} \longleftrightarrow \mathrm{NiOOH}+\mathrm{e}^{-}
$$

Nickel oxide films can be deposited on an ITO-coated glass by anodic electrochemical deposition or by sputtering followed by hydration in basic electrolytes. The electrochromic characteristics of the films vary according to the preparation procedure: the films produced by sputtering have a good cycling ability while those grown electrochemically have faster time response ${ }^{1}$.

The reasons of this difference are not fully clear and they may tentatively be explained with the fact that the electrochemical process for the original sputtered $\mathrm{NiO}$ film requires a gradual but progressive hydratation to a $\mathrm{NiO}_{\mathrm{x}} \mathrm{H}_{\mathrm{y}}$ form of unknown stoichiometry. However, differences in the basic structure of the two types of nickel oxide films, cannot be explained'.

\section{NEW OXIDES WITH "ANODIC COLORATION" ASSOCIATED WITH A REVERSIBLE $\mathrm{Li}^{+}$-INSERTION PROCESS}

To our knowledge, little work has been reported on efficient electrochromism associated with a reversible $\mathrm{Li}^{+}$insertion process occurring in nickel (or iridium)based oxide films. This drawback has to be overcome since long term electrochemical stability, at elevated temperature, of EC display elements is likely to occur when $\mathrm{Li}^{+}$rather than $\mathrm{H}^{+}$(or $\mathrm{OH}^{-}$) is used as the mobile specie ${ }^{2-4}$. However let us point out that Scrosati et al. and Buffat et al. recently reported reversible $\mathrm{Li}^{+}$insertion in nickel oxide-based films ${ }^{8-10}$.

On the other hand, we have recently shown that a large variety of compounds selected among lithium-based transition metal oxide electrodes of class (b) also undergo a reversible $\mathrm{Li}^{+}$insertion process: we have indeed recently patented a new strategy and related experiments that has enabled us to introduce a new family of highly efficient EC lithium-based transition metal oxide electrodes of class (b) ${ }^{11}$.

In fact, the strategy consists of:

(i) investigating lithium-based transition metal oxides whose structure does not necessarily allow an efficient reversible-electrochemical $\mathrm{Li}^{+}$insertion process.

(ii) inducing or improving the reversible $\mathrm{Li}^{+}$insertion process by reducing the size of the crystalizes of the semiconductor: Consequently the reversible $\mathrm{Li}^{+}$insertion process, and thereby the EC effect, would be highly efficient for (X-ray amorphous) lithiated films whose texture consists of microcrystallizes of less than $50 \AA$ size $^{11.12}$.

In other words we speculate that good electrochromic properties can be obtained, and can result from fast diffusion, and/or migration, of $\mathrm{Li}^{+}$ions along the grain boundaries of crystalline which themselves may have low ionic conductivity ${ }^{13}$. We will illustrate here these concepts on a new ECM of composition:

$$
\begin{gathered}
\mathrm{Li}_{1-x}^{+} \mathrm{Cr}_{1-x}^{3+} \mathrm{Cr}_{x}^{4+} \mathrm{O}_{2}^{2-} \\
\text { with } 0 \leqslant \mathrm{x} \leqslant 0.4
\end{gathered}
$$


TABLE 1

Experimental conditions for the reactive RF sputtering of lithium and chromium-based films.

\begin{tabular}{ll}
\hline Target & $\mathrm{LiCrO}_{2}$ \\
Initial pressure & $10^{-5} \mathrm{mbar}$ \\
Atmosphere & $\mathrm{Ar}$ \\
Pressure & $10^{-2} \mathrm{mbar}$ \\
Sputtering time & $60 \mathrm{mn}$ \\
Film thickness & $1100 \mathrm{~A}$ \\
\hline
\end{tabular}

\section{III-1. Film deposition}

Float-glass substrates of $50 \times 50 \mathrm{~mm}$ size, coated with a thin layer of transparent electronic-conductive material (ITO: Indium Tin oxide) have been used. The chromium-based films were prepared by RF sputtering, at room temperature, of home made targets of $100 \mathrm{~mm}$ diameter (table 1).

\section{III-2. Electrochromic properties}

The electrochemi-chromic testing have to be processed within an appropriate voltage range so as to avoid electrolyte oxidation and (eventual) ITO reduction.

Corresponding coloring and bleaching cycles of the chromium-based films are reported in figure 1: the $\mathrm{Li}^{+}$electrochemical (des)insertion was readily reversible; the charge transferred was as high as $3 \times 10^{3} \mathrm{C} / \mathrm{cm}^{3}$ even after $10^{4}$ cycles. The knowledge of the range of film specific weigh of $3-4 \mathrm{~g} / \mathrm{cm}^{3}{ }^{13}$ would give, a modulation of the lithium content of about 0.4 .

In such a case, the reversible intercalation process, occurring in the film, could be depicted as follows:

$$
\mathrm{Li}^{+} \mathrm{Cr}^{3+} \mathrm{O}_{2}^{2-} \longleftrightarrow \mathrm{Li}_{0.6}^{+} \mathrm{Cr}_{0.6}^{3+} \mathrm{Cr}_{0.4}^{4+} \mathrm{O}_{2}^{2-}+0.4 \mathrm{Li}^{+}+4 \mathrm{e}^{-}
$$

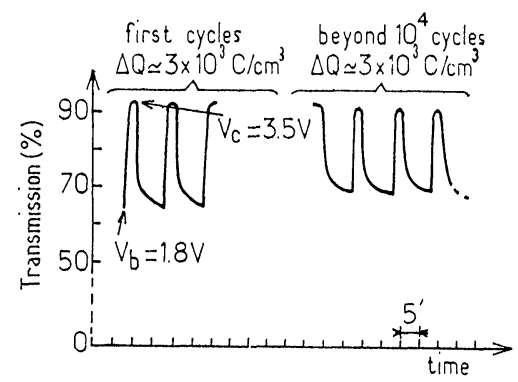

FIGURE 1 Transmission $(\lambda=550 \mathrm{~nm})$ vs time, for repeated colouring and bleaching cycles, of the ECM: $\mathrm{Li}_{1-x}^{+} \mathrm{Cr}_{1-x}^{3+} \mathrm{Cr}_{x}^{++} \mathrm{O}_{2}^{2-}$, performed in $1 \mathrm{M} \mathrm{LiClO}_{+}^{-}$-prolylene carbonate electrolyte. The potentials are measured versus a $\mathrm{Li}$ counter electrode. 


\section{ELECTROCHROMIC WINDOWS}

For sake of clarity we will symbolize in the following:

-the ECM with "cathodic coloration", associated with a reversible $\mathrm{Li}^{+}$insertion process such as $\mathrm{WO}_{3}$, as $\mathrm{ECM}_{1}\left(\mathrm{Li}^{+}\right)$.

-the ECM with "anodic coloration", - associated with a reversible $\mathrm{Li}^{+}$insertion process such as $\mathrm{Li}_{1-x} \mathrm{CrO}_{2}$, as $\mathrm{ECM}_{2}\left(\mathrm{Li}^{+}\right)$.

An electrochromic window (ECM) can be likened to an electrochemical cell where the $\mathrm{ECM}_{1}\left(\mathrm{Li}^{+}\right)$and the $\mathrm{ECM}_{2}\left(\mathrm{Li}^{+}\right)$are separated by a suitable $\mathrm{Li}^{+}$ionic conductor IC $\left(\mathrm{Li}^{+}\right)$.

Figure 2 schematically illustrates the method of operation of a ECW that involves the two ECM $\left(\mathrm{Li}^{+}\right)$, - deposited on an ITO coated glass substrate, separated by a $\mathrm{Li}^{+}$ionic conductor IC $\left(\mathrm{Li}^{+}\right)$. By applying a voltage between $\mathrm{ECM}_{1}\left(\mathrm{Li}^{+}\right)$and $\mathrm{ECM}_{2}\left(\mathrm{Li}^{+}\right)$the electrochromic process can be promoted so that to induce color-
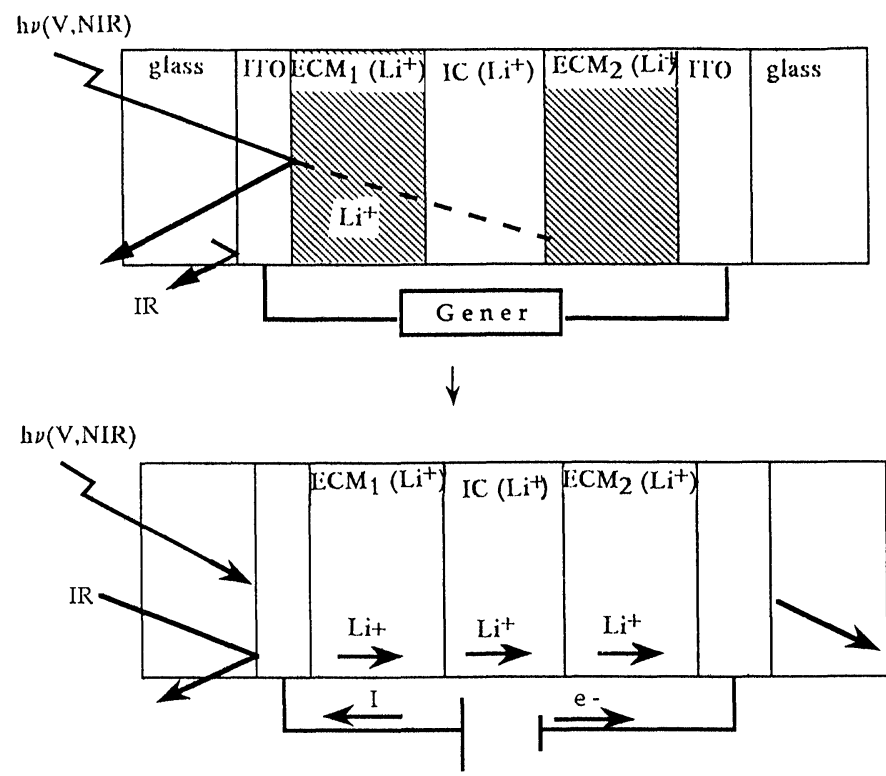

Transition from opaque to transparent state
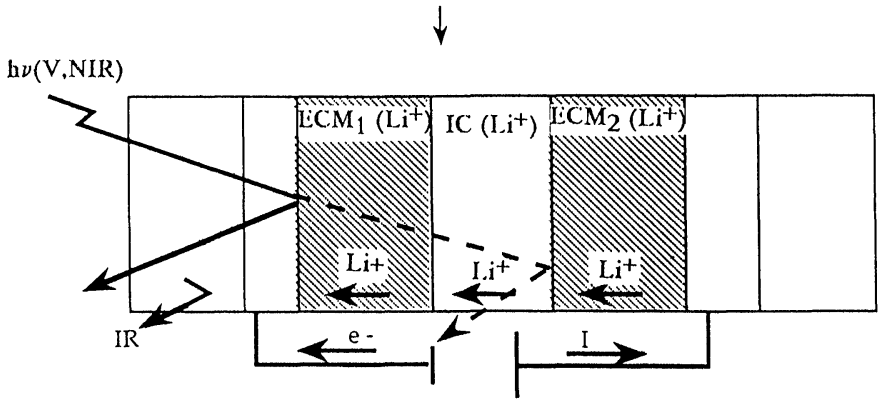

FIGURE 2 Method of operation of an electrochromic window (ECW). 


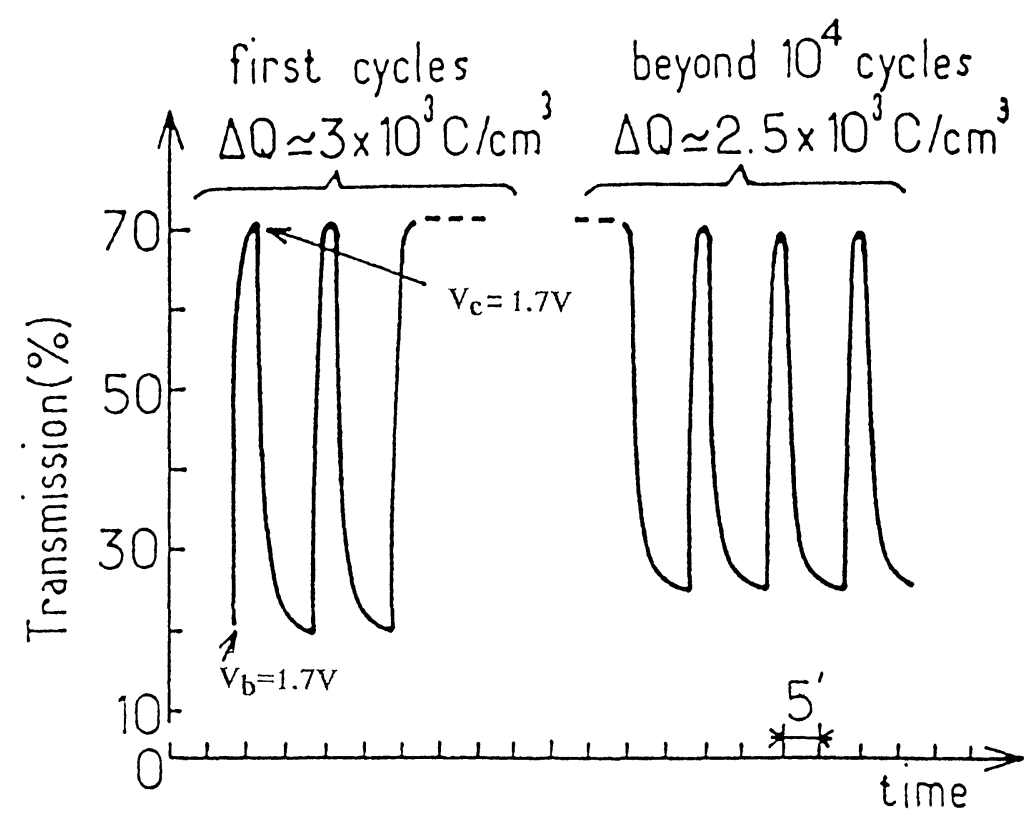

FIGURE 3 Transmission $(\lambda=550 \mathrm{~nm})$ vs time, for repeated colouring and bleaching cycles, of the ECW: $\mathrm{Li}, \mathrm{WO}_{3} / \mathrm{IC}\left(\mathrm{Li}^{+}\right) / \mathrm{Li}_{1-\mathrm{x}} \mathrm{CrO}_{2}$.

ation by cathodic polarization of $\mathrm{ECM}_{1}$ (formation of colored "inserted" $\mathrm{Li}_{\mathrm{x}} \mathrm{ECM}_{1}$ ) and, consequently, by anodic polarization of $\mathrm{ECM}_{2}$ (formation of colored "desinserted" $\mathrm{Li}_{\mathrm{y}-\mathrm{x}} \mathrm{ECM}_{2}$ ). A reverse polarization restores the bleached state of the $\mathrm{ECW}$ (formation of transparent "desinserted" $\mathrm{ECM}_{1}$ and of transparent "inserted" $\mathrm{Li}_{\mathrm{y}} \mathrm{ECM}_{2}$ ).

Obvious requirements of reliability and practicity, call for the replacement of the traditional liquid electrolyte display configuration with an improved design that includes the use of a plastic-like IC $\left(\mathrm{Li}^{+}\right)$, possibly in the form of thin-film polymer layers. We have obtained very promising results with ECW using $\mathrm{Li}^{+}$conducting

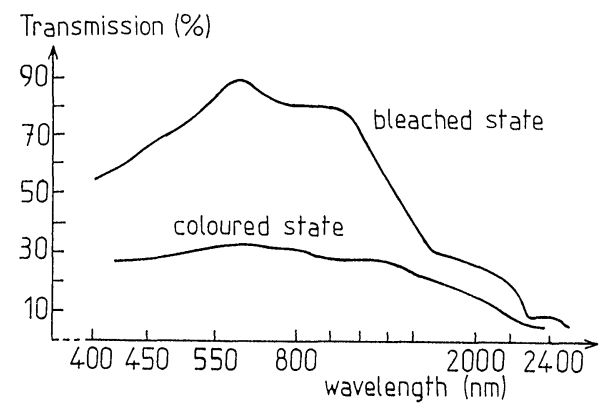

FIGURE 4 Transmission spectra (beyond $10^{4}$ cycles) of the ECW: $\mathrm{Li}_{\mathrm{x}} \mathrm{WO}_{3} / \mathrm{IC}\left(\mathrm{Li}^{+}\right) / \mathrm{Li}_{1-\Upsilon} \mathrm{CrO}_{2}$. 
polymers as IC $\left(\mathrm{Li}^{+}\right), \mathrm{WO}_{3}$ as $\mathrm{ECM}_{1}\left(\mathrm{Li}^{+}\right)$and $\mathrm{Li}_{1-x} \mathrm{CrO}_{2}$ as $\mathrm{ECM}_{2}\left(\mathrm{Li}^{+}\right)$. These promising results are illustrated in figure 3 and 4. Fig. 3 gives, indeed, evidence of the expected repetitive cycling behaviors of the system. In addition, an equally expected net electrochromic effect occurs (fig. 4); it involves the passage of lithium from one electrode to the other, depicted by the reaction:

$\mathrm{Li}^{+} \mathrm{Cr}^{3+} \mathrm{O}_{2}^{2-}+\mathrm{W}^{6+} \mathrm{O}_{3}^{2-} \longleftrightarrow \mathrm{Li}_{1-x}^{+} \mathrm{Cr}_{1-x}^{3+} \mathrm{Cr}_{x}^{4+} \mathrm{O}_{2}^{2-}+\mathrm{Li}_{\mathrm{x}}^{+} \mathrm{W}_{1-\mathrm{x}}^{6+} \mathrm{W}_{\mathrm{x}}^{5+} \mathrm{O}_{3}^{2-}$

clear $(\mathrm{Cr} 3+) \quad$ clear green $(\mathrm{Cr} 4+)$ blue

\section{REFERENCES}

1. B. Scrosati, Chimicaoggi, 44, June (1989).

2. S. Morisaki, K. Kawakami and N. Baba, Jap. J. Appl. Phys., 27, 314 (1988) and references therein.

3. M.F. Daniel, B. Desbat, J.C. Lassegues and R. Garie, J. Solid State Chem., 73, 127 (1988)

4. M. Ottariani, S. Panero, S. Morzilli, B. Scrosati and M. Lazzari, Solid State Ionics, 20, 197 (1986).

5. S. Hackwood, A.H. Daymen and G. Beni., Phys. Rev. B, 26, 471 (1982).

6. M. Fantini and A. Gorenstein, Solar En. Mat., 16, 487 (1987).

7. P. Delichère, S. Joiret, A. Hugot le Goff, K. Bange and B. Hetz, J. Electrochem. Soc., 135, 1856 (1989).

8. S. Passerani, B. Scrosati, A. Gorenstein, A.M. Anderson and G.C. Grangrist, Proc. Electrochem Soc., 90-2 (Proc. Symp. electrochromic Mat., 1990), 237 (1990).

9. S. Passerani, B. Scrosati, A. Gorenstein, J. Electrochem Soc., 137, 3297 (1990).

10. B. Buffat, F. Lerbet, F. Defendini and C. Padoy, Brevet Saint Gobain Vitrage (1988) n ${ }^{\circ} 8815086$, Imprimerie Nationale, 27 rue de la Concention, 75732 Paris cédex 15.

11. J.P. Coupit, G. Campet, B. Morel, J.M. Chabagno, D. Ferry, M. Bourrel, R. Garie, C. Delmas, C. Geoffroy, J. Portier, J. Salardenne, R. Dirkx, United States Patent Application, (1989), réf.: MNTC-010, Finnegan, Henderson, Farabow, Garret and Dunner, Washington, (U.S.A.).

12. B. Morel, G. Campet, B. Darrier, F. Veil and J. Portier (in preparation).

13. B. Morel, G. Campet, J. Salardenne, J. Portier, C. Delmas, M. Bourrel, J.M. Chabagno, and D. Ferry (in preparation). 

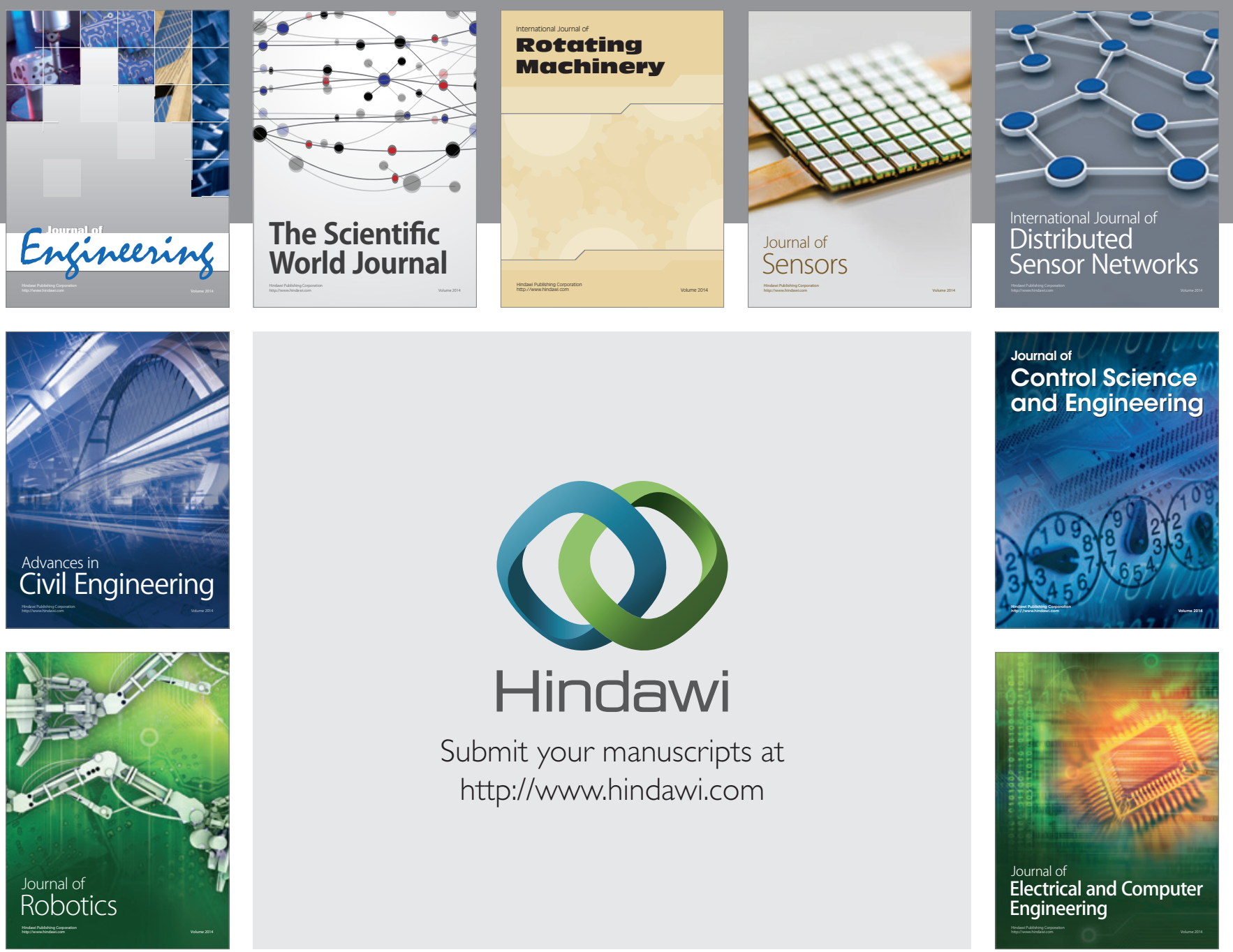

Submit your manuscripts at

http://www.hindawi.com
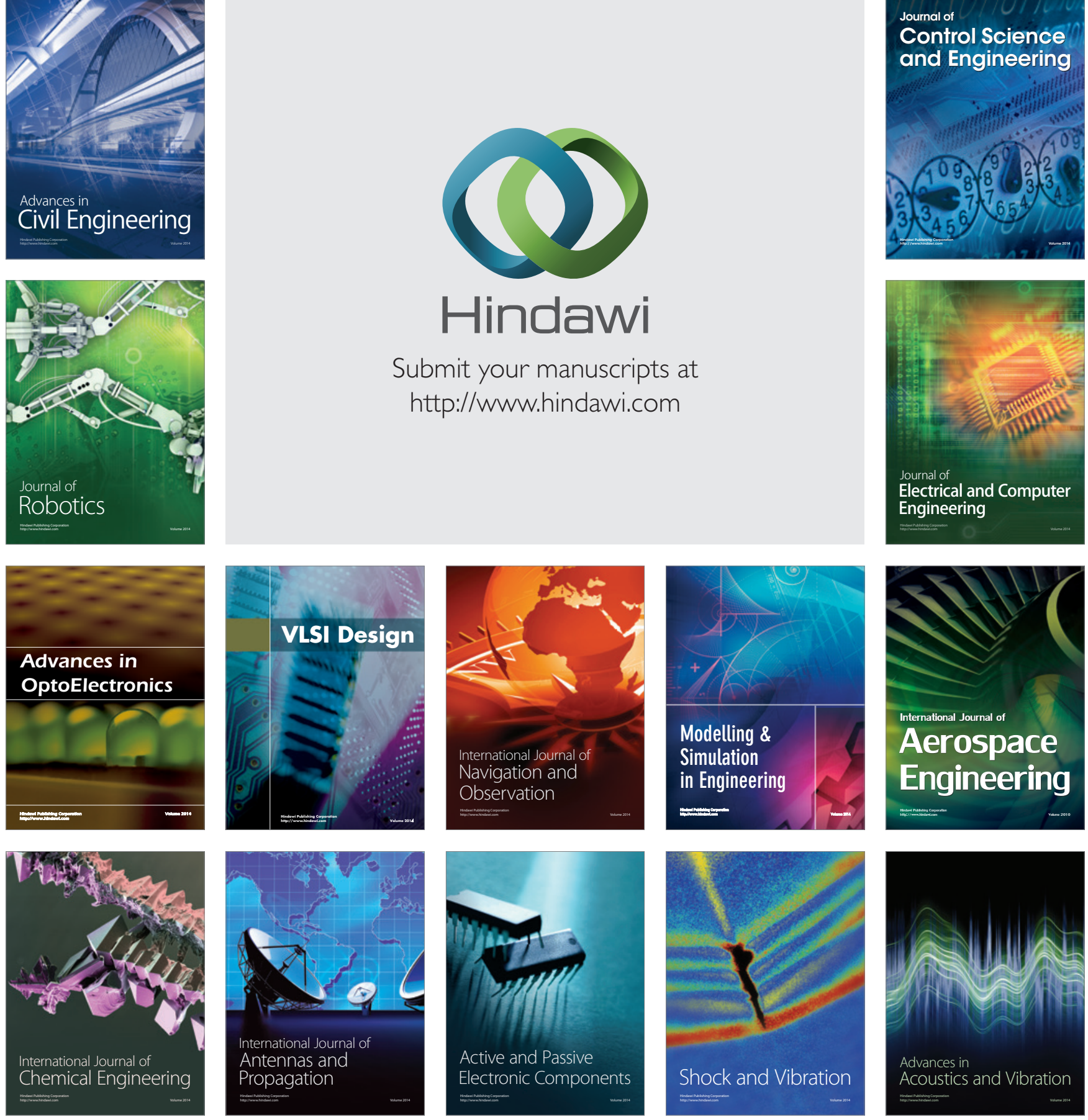